\title{
Polish legal regulations considering recovery of secondary materials from coal mining dumping grounds
}

\author{
Łukasz Gawor \\ Silesian University of Technology, Akademicka Str. 2a, 44-100 Gliwice, Poland \\ E-mail address: lukasz.gawor@polsl.pl
}

\begin{abstract}
In the article there is presented temporary situation of coal mining dumping grounds in Poland - their inventarization, localization and environmental impacts. The coal mining dumping grounds in Poland are situated in three coal basins: Upper Silesian Coal Basin, Lower Silesian Coal Basin and Lublin Coal Basin. In all mentioned areas occur ca. 270 coal mining waste dumps, covering surface of over 4400 ha. The main environmental impacts connected with dumping grounds are fire hazards, water pollution and a danger of slope sliding. The question of recovery of coal from disposed wastes with regard to legal regulations is discussed. There are presented technical methods of coal recovery considering environmental protection issues. There is a necessity and technical possibility of recovery of coal from the coal-mining waste dumps. The coal recovery reduces hazards of self-ignition and fires of the dump. It is also economically justified. The analysis of required regulations in legal system in Poland for safe exploitation of secondary materials from coal mining dumps is done. Socio-economic aspects of recovery of coal are discussed. The valid legal regulations in Poland regulate the issues connected with coal mining dumping grounds in a very general way. It is necessary to prepare supplements to the legal provisions or new regulations concerning post-mining dumping grounds.
\end{abstract}

KEY WORDS: mining waste dumps, anthropogenic resources, law deeds

\section{Introduction}

The coal mining industry in Poland generates approximately 30 million $\mathrm{Mg}$ of mining wastes per year. According to various sources, it is estimated that for each $1 \mathrm{Mg}$ of coal produced, there is $0.4-0.5 \mathrm{Mg}$ of waste material (SZCZEPAŃSKA \& TWARDOWSKA, 1999; GAWOR, 2014). This results in the disposal of a huge volume of wastes at dumping grounds. The coal mining waste dumps are spread within the area of over 4,000 ha in more than 260 dumping sites, where over 760 million Mg of wastes from hard coal mining have been disposed.

One of the significant problems in Polish coal mining industry is the recovery of coal from mining wastes. There are a possibility and necessity to recover coal from mining waste dumps, which should be linked with appropriate legal regulations.

Coal mining waste dumps may be considered as important secondary deposits. Feasibility studies and past experiences in the coal recovery show a need for new recovery sites. Sustainable coal recovery is not only economically but also ecologically justified. The re-using and managing of reclaimed dumping sites for local communities is also of importance.

\section{Coal mining dumping grounds in Poland}

The coal mining dumping grounds in Poland are situated in three coal basins: Upper Silesian Coal Basin, Lower Silesian Coal Basin and Lublin Coal Basin. According to the recent study (20132014), in the Upper Silesian Coal Basin occur ca. 220 coal mining waste dumps, covering over 4000 ha. The highest concentration of the dumps occurs in the central part of the USCB, i.e. in Bytom (21 dumps), Ruda Śląska (12 dumps) and Zabrze (34 dumps), as well as in the south-western part of the USCB, i.e. in Rybnik (13 dumps) and Jastrzębie-Zdrój - 4 dumps (GAWOR, 2014).

According to the literature study in the Lower Silesian Coal Basin there are 39 coal-mining 
waste dumps. The majority of the dumps (23) has volume of dozen - several thousands of $\mathrm{m}^{3}$. Total surface of coal mining waste dumps covers ca. 305 ha, the volume reaches 65 million $\mathrm{m}^{3}$ (WóJCIK, 2007, 2012). In the Lublin Coal Basin there is only one waste dump which covers 65 ha and is going to be enlarged up to 88 ha (www.lw.com.pl).

Coal mining dumping grounds cause different environmental problems. One of the most dangerous environmental impacts of coal mining waste dumps are fire hazards. The lack of waste material compacting, as well as the ignorance of rules regarding fire prevention, causes numerous spontaneous combustion processes, particularly in old coal mining waste dumps. Coal substance and pyrite present in waste material undergo intensive oxidization, which leads to self-ignition inside the dump. A burning dump may affect its surroundings due to spreading the fire and causing air pollution (GAWOR, 2013, 2014).

Another important environmental impact of mining wastes is surface water and groundwater pollution. There is a well-known problem of AMD processes (acid mine drainage). Recovery of coal may result in changes to the hydrogeochemical profile of the anthropogenic vadose zone, arising from the re-mining and re-disposal of coal extractive waste (STEFANIAK \& TWARDOWSKA, 2005, GRAY, 1997 ). The significant problem is also a lack of systematical groundwater monitoring on and around the waste dumps as well as law regulations, concerning particular requirements according to the mentioned above monitoring systems (GAWOR ET AL., 2011).

A serious environmental problem connected with the disposal of mining wastes is a danger slope sliding. The old conical dumps are the most susceptible to the mentioned processes, which usually start with erosion troughs. The natural erosion processes may be intensified by anthropogenic activities e.g. illegal cycling on the dump surface (GAWOR, 2014).

The environmental impacts of dumping grounds may be reduced by the recovery of coal from coal mining waste dumps. According to the data from coal recovery companies, it is possible (by means of recovery of coal and selling part of waste rock as aggregates) to reduce the volume of the dumps up to $45 \%$ (M. Redoute - personal communication).

\section{Possibilities of recovery of coal from post mining dumps}

There is a technical possibility of recovery of coal from the coal-mining waste dumps. The coal recovery reduces hazards of self-ignition and fires of the dump. It is also economically justified (GAWOR, 2013, 2014).

In the past there were few examples of successive recovery of coal from the dumps both in Upper Silesian Coal Basin and Lower Silesian Coal Basin (e.g. Central Mining Waste Dump in Smolnica, waste dumps in Buków, Czerwionka). Some of the dumps are being exploitated - e.g. waste dump in Panewniki, Central Mining Waste Dump in Knurów, waste dump in Wałbrzych by Moniuszki street. There are several companies which conduct recovery of coal as well as reclamation of the dumps using different preparation technologies.

First required step in a process of coal recovery is drilling campaigne. The average number of drillholes is 1 drillhole per 1 ha. Obtained samples undergo following laboratory tests:

- preparing of the samples,

- ash and moisture content (PN-ISO 589, PN80/G-04512),

- sulphur content (PN-81G-04514.02),

- calorific value (PN-81/6-04513),

- Sink \& Float Analysis with defining of ash, sulphur and calorific value content.

The technology of preparation of dump material is similar as in the preparation plant of a coal mine. The preparation plant uses wet preparation method with applying of dense medium (e.g. magnetite), starting segregation by screening in the grain size classes 1-60 $\mathrm{mm}$ and 0,25-1 $\mathrm{mm}$, through the process of beneficiation and classification of the material in hydrocyclones till the end phase of dewatering in centrifuge. The installation may be mobile, built of modules, which construction lasts from 10 till 15 weeks.

Due to the fact that the amount of coal in the waste material may be up to $10 \%$ (between 3-10\%, with the assumption that an average amount of coal to be recovered accounts for $5-7 \%$ ), it can be estimated that total potential amount of recovered coal from the dumps in the USCB shall account for more than 45 million $\mathrm{Mg}$ (GAWOR, 2013, 2014).

\section{Legal regulations considering recovery of materials from coal mining dumping grounds}

The valid legal regulations in Poland regulate the issues connected with coal mining dumping grounds in a very general way. It is necessary to prepare supplements to the legal provisions or new regulations concerning post-mining dumping grounds. It seems to be beneficial to create new regulations in the form of local law deeds. 
The implementation of the first EU directive concerning mining waste (Directive 2006/21/EC of the European Parliament and of the Council on the management of waste from the extractive industries) has taken place in Poland recently. There is, however, a need of creating regulations regarding waste dumps on the level of selfgovernment, i. e. Voivodeship in Upper Silesia.

The recovery of coal due to the latest legal regulations in Poland is essential. The main rule of waste management in Poland, pursuant to the Act on Waste (Ustawa z 27.04.2001r. o odpadach, art. $5 \mathrm{pkt}$.2), requires to ensure an environmentally compliant recovery, should there be no possibility to avoid the production of wastes. The owner of the wastes should, in the order of priority, treat them under the recovery process, and if it is not technologically possible or economically justified, the owner shall take the necessary measures to ensure that waste management is carried out without endangering human health and without harming the environment with the use of Best Available Techniques (BAT`s).

Required permissions:

1) According to art. 54a of Act on Waste (Ustawa o odpadach) exploitation of wastes from the dump requires obtaining a permission for generating wastes. The institutions giving such permissions according to art. 378 of Environmental Law (Prawo ochrony środowiska), are: marshall of the voivodeship, head of the poviat starosty or regional director of environmental protection.

2) It is necessary to get decision concerning construction permit. This permit is given by architecture-construction administration (the most often poviat starosty). The procedure is limited by regulated by art. 36a of Construction Law (Ustawa Prawo budowlane).

3) Preparation of wastes from extractive industry (particularly waste excavated from the dumps) requires destination permission for recovery (using) of wastes (art. 26 of Act on Waste (Ustawa o odpadach). The suitable institution in this case is: marshall of the voivodeship, head of the poviat starosty or regional director of environmental protection.

4) In spite of permission for recovery it may be also necessary obtaining of permit for transport or collecting of wastes, which is given by the head of the poviat starosty, based on art. 28 of Act on Waste (Ustawa o odpadach).

5) According to regulations of reclamation rules it is required obtaining of decision in the case of recloamation. This decision is given by the head of the poviat starosty based on art. 22 of Act on
Protection of agriculture and forest grounds (Ustawa o ochronie gruntów rolnych i leśnych).

6) All the documents and elaborations connected with the procedure of giving required permits will be published for the interested community.

\section{Socio-economic aspects of recovery of coal}

The recovery of coal from the dumps may have significant influence on the local communities particularly inhabitants living in the neighborhood of the dumps. Constructing the preparation plant requires mentioned above permissions, which also should be given to the public information of interested community.

The definition of interested community sounds: Natural persons, legal persons or organization units not having legal personality, which may be affected by the consequences of the permit or have interest in the process of giving of the permit (Act on Wastes from extractive industry Ustawa o odpadach wydobywczych).

The local community must be informed about the procedure of giving permits, especially concerning:

- application of giving the permit,

- details about institutions resposible for the decisions,

- character of possibile decisions.

The interested community has legal right to give remarks and opinions to suitable institutions before taking decisions. The results of consultations and opinions are taken into consideration during decision process. When the decision has been taken, suitable institution informs interested community.

The functioning of recovery installation is linked with potential threats for the natural environment. The interested society have often uncertainties or apprehensions concerning safety of this process. There are e.g. uncertainties about negative impacts on air (dust emissions), noise limits, degradation of landscape etc.

As far as the noise is concerned the sound level intensity of the operating preparation plant does not exceed $55 \mathrm{~dB}$ (based on many years experience), what suits to the standard of permissible noise level for single-family residential buildings in accordance with ordinance of permissible noise level in the environment Environmental law (Rozporzadzenie $w$ sprawie dopuszczalnych poziomów hałasu w środowisku Prawo ochrony środowiska). In case of exceeding of noise standards there is a possibility of constructing acoustic barriers.

The danger of dust pollution during preparation of coal mining wastes is reduced by applied wet 
preparation technology. Extended dust emissions connected with heavy transport is limited by sprinkling of technology and public roads. Heavy transport is reduced by applying rail transport and conveyor belts.

Regarding planned localization of preparation plant in the direct neighborhood of coal mine and dump the plant will not interfere the landscape it will be a part of existing industrial areas. After exploitation of the dump its volume will be reduced of ca. $15 \%$. There will be thus positive changes in the landscape because of the reduction of height and surface of the dump. The feasibility study of one dump in USCB proves that recovery of coal is economically justified. There is an example of one of the dumps called ' $X$ ', costs and benefits analysis (Tab. 1).

Table 1. Economical analysis of the coal-mining waste dump 'X' in USCB

(source: Gawor, 2014 after Analysis of Ipas Polska sp. z o.o., unpublished)

\begin{tabular}{|l|c|}
\hline \multicolumn{1}{|c|}{ Expenses and profits } & Thousands of PLN (general) \\
\hline Total sales & 160,000 \\
\hline Profit before taxation and interest & 50,000 \\
\hline Interest & 4,3 \\
\hline Taxation & 8,5 \\
\hline Net profit & 35,000 \\
\hline Add Amortization & 20,000 \\
\hline Net Capital Generated & 55,000 \\
\hline Purchase Consideration Capital Expenditure & 20,000 \\
\hline Net Cash Available & 35,000 \\
\hline
\end{tabular}

\section{Conclusions}

Coal mining dumping grounds may be potential anthropogenic secondary deposits. The recovery of coal is technically possible and economically justified. According to the Act on Waste it is also a priority. The safety of recovery processes requires obeying legal regulations, included in different acts and deeds, connected with environmental protection, waste management and reclamation.

As far as the legal regulations are concerned so far no standards, technical specifications or legal law acts have been prepared in Polish legislation which would in detail refer to dumping grounds of hard coal mining waste. The valid legal acts (statutes and resolutions) regulate the issues connected with dumping grounds' reclamation and development in a very general way. It is necessary to prepare supplements to legal provisions or new regulations concerning post-mining dumping grounds in Poland. It seems to be beneficial to create new regulations modeled on the German example in the form of local law acts (e.g. Voivod's Resolutions), elaborations of standards or technical specifications.

\section{References}

Gawor Ł., Jankowski A.T., Ruman M. 2011. Post-mining dumping grounds as geotourist attractions in the Upper Silesian Coal Basin and the Ruhr District. Moravian Geogr. Reports, 19, 4: 61-68.

Gawor Ł. 2013. Environmental impact of coal-mining wastes in Poland with regard to legal regulations. [in:] Proc. of 14th conf. with international participation "Waste Management - GzO'13”, Kortnik J. (ed.), Krsko: 102-108.

Gawor Ł. 2014. Coal mining waste dumps as secondary deposits exemplified on Upper Silesian Coal Basin and Lublin Coal Basin. Geol., Geoph. and Environ., 39.

Gray N.F. 1997. Environmental impact and remediation of acide mine drainage: a management problem. Environ. Geol., 30: 62-71.

Szczepańska J., Twardowska I. 1999. Distribution and environmental impact of coal mining wastes in Upper Silesia. Poland. Environ. Geol., 38, 3: 249-258.

Szczepańska J., Twardowska I. 2004. Mining waste. [in:] Twardowska et al. (eds.) Solid waste: assessment, monitoring and remediation. Elsevier, Amsterdam: 319-386.

Wójcik J. 2007. Rekultywacja hałd na terenach górniczych wałbrzyskich kopalń węgla kamiennego w latach 19602005. Przegl. Górn., 63 (3): 23-28.

Wójcik J. 2012. Wałbrzyskie hałdy i osadniki kopalniane jako źródło surowców wtórnych - wstępne wyniki inwentaryzacji. Przegl. Geol., 60, 4: 212-219.

www.lw.com.pl 